\title{
Conceptual socialization in EFL contexts: A case study on Turkish EFL learners' request speech acts realization
}

\author{
Merve Şanal $^{\text {a* iD }, \text { Deniz Ortaçtepe }}{ }^{\text {b (iD }}$ \\ ${ }^{a}$ Bilkent University, Ankara 06800, Turkey \\ ${ }^{b}$ Middlebury Institute of International Studies, Monterey, CA 93940, USA
}

\begin{abstract}
APA Citation
Sanal, M., \& Ortactepe, D. (2019). Conceptual socialization in EFL contexts: A case study on Turkish EFL learners' request speech acts realization. Journal of Language and Linguistic Studies, 15(1), 376-399.
\end{abstract}

Submission Date: 30/04/2018

Acceptance Date: 21/11/2018

\begin{abstract}
Conceptual socialization refers to the process second/foreign language learners go through to transform their conceptual system so as "to fit the functional needs of the new language and culture" (Kecskes, 2002, p. 157). Therefore, the present study examined Turkish EFL learners' conceptual socialization by analyzing the similarities and differences between native speakers of English and Turkish learners of English in their request speech acts realization. The data were collected from Turkish learners of English (focal group) and native speakers of English (baseline group) through role-plays and a written discourse completion task on requests both in Turkish and English. Participants' responses were rated in terms of the level of formality, politeness, directness and appropriateness. The results indicated that although the Turkish EFL learners were higher level learners, they could not produce the required level of politeness, formality and appropriateness in their speech acts as much as the native speakers did. This study reveals that in EFL contexts, where there is lack of authentic social interaction and engagement with a community of practice, language learners' conceptual socialization process is bound to their experiences of classroom instruction and L1 socialization.
\end{abstract}

(C) 2019 JLLS and the Authors - Published by JLLS.

Keywords: Conceptual socialization; English as a foreign language; pragmatic competence; request speech acts; sociolinguistics.

\section{Introduction}

Second language (L2) learners have difficulty in developing pragmatic competence and communicating appropriately in different social interactions in L2 due to their limited knowledge of the cultural values and norms of the target language culture (e.g., Bardovi-Harlig \& Hartford, 1993; Ellis, 1992; Li, Suleiman \& Sazalie, 2015; Ortactepe, 2012; Taguchi, 2012). According to Kecskes and Papp (2000), L2 learners' difficulties in language learning not only stem from grammatical or lexical

\footnotetext{
* Corresponding author. Tel.: +1-347-420-6812

E-mail address: msanal@bilkent.edu.tr
} 
deficiencies but also from a lack of conceptualization in the target language and culture. The researchers, therefore, propose the term conceptual socialization to explain the language socialization process L2 learners go through in a second/foreign language. According to Kecskes (2002), conceptual socialization is "the transformation of the conceptual system which undergoes characteristic changes to fit the functional needs of the new language and culture" (p. 157). In other words, L2 learners should be acknowledged as individuals who have already completed their L1 socialization in their L1 culture. Thus, what L2 learners will experience as part of their L2 socialization is conceptual transformation based on two interacting processes: becoming aware of the conceptual differences between the two cultures and languages and developing a bilingual identity.

Speech acts, which are functional units in communication (e.g., requests, promises and apologies), have long received the attention of researchers interested in L2 learners' pragmatic competence since they can reflect the cultural norms and values of a society (e.g., Blum-Kulka \& Olshtain, 1984; Lee, 2004; Lu, 2001; Ming-Fang Lin, 2014; Pinto \& Raschio, 2007; Siebold \& Busch, 2015). While studies on speech acts focused on L2 socialization or pragmatic socialization of L2 learners (Matsumura, 2001; Poole, 1994;), conceptual socialization is still a budding framework and studies on L2 learners' conceptual socialization is limited to their acquisition of formulaic expressions in EFL contexts (Ortactepe, 2012). Therefore, the present study aims to explore Turkish EFL learners' conceptual socialization in their realization of request, refusal and acceptance speech acts in terms of the level of formality, politeness, directness and appropriateness in written and oral activities.

\subsection{Theoretical Framework}

\subsubsection{Conceptual Socialization}

According to Schieffelin and Ochs (1986), language socialization refers to "a process requiring children's participation in social interactions so as to internalize and gain performance competence in these socio-cultural defined contexts" (p. 2). While Schieffelin and Ochs' (1986) framework of language socialization is mostly concerned with children acquiring their first language (L1), this framework is applied to L2 acquisition in which L2 learners are viewed "as novices being socialized into not only a target language but also a target culture" (Leung, 2001, p. 1). Within the framework of L2 socialization, learning a second/foreign language comprises learning about both linguistic features of the target language and how to use them in different social interactions, a process that can be achieved through being exposed to and participating in the target language interactions (Matsumura, 2001). Studies on L2 socialization focused on both social aspects and pragmatic aspects of language development (e.g., Kasper, 1992; Matsumura, 2001; Willet, 1995). For instance, Matsumura (2001) investigated Japanese university students' socio-cultural perceptions and pragmatic use of English while giving advice in a 12-item multiple choice questionnaire. There were two groups of participants: Japanese exchange students in Canada and Japanese students in Japan. It was observed that being in the target environment had positive effects on pragmatic competence when offering advice to inferiors and people of equal social status but not higher status. Although both groups developed some L2 pragmatic competence, transferring L1 socialization to the L2 context was observed in some cases for the group in the target language culture.

According to Kecskes (2015), when a new language is added to L1-governed pragmatic ability, bilingual pragmatic development is affected more "by individual control, consciousness and willingness" to acquire specific social skills (p. 1). Therefore, he proposes the term conceptual socialization to underline the differences between L1 and L2 acquisition. To begin with, language socialization in L1 is both linguistically and socially subconscious; however, more consciousness and deliberate choices are involved in L2 socialization (Kecskes, 2015; Ortactepe, 2012). Sometimes, language learners may know the norms and expected expressions to use in the target language (e.g., 
'have a nice day'), but they may deliberately opt out to use them when they find them inappropriate in their own cultures (Kecskes, 2015). Secondly, age and the attitudes of bilinguals affect their language learning as "the later the L2 is introduced the more bilinguals rely on their L1 dominated conceptual system, and the more they are resistant to any pragmatic change that is not in line with their L1-related value system, conventions and norms" (Kecskes, 2015, p. 9). Another aspect that makes conceptual socialization different from language socialization is related to learners' access to the target sociocultural environment. While social and linguistic development go hand in hand in L1 socialization due to the direct access to L1 social norms, values and beliefs, L2 learners have limited access to target language culture. Kecskes (2015) states that "in the second language, pragmatic socialization is more about discourse practices as related to linguistic expressions than how these practices relate to cultural patterns, norms and beliefs" (p. 10). That's why, language learners may easily reach the grammatical structures but not the sociocultural background where those structures are conventionally used. This process is even more challenging in cases where opportunities for language use are bound to social, political and cultural factors influencing learners' identity and power relations within the target language community. For instance, in her longitudinal, mixed-methods study with international students arriving in the United States as newcomers, Ortactepe (2012) concluded that conceptual socialization in L2 depends mostly on learner's investment in the language rather than extended social networks.

\subsubsection{Speech Acts}

Austin's theory of speech acts (1962) suggests that "utterances have three kinds of meaning" (p. 10). The first meaning is propositional or locutionary meaning which refers to the literal meaning of the sentence. For instance, when the utterance 'It is dark in here' is used, the locutionary meaning would concern the little or no light in the room. The second meaning is illocutionary, which is the intent of a locution, in other words, the social function that the utterance has. As an illocutionary act, 'It is dark in here' might function as a request to turn on the lights. Perlocutionary force is involved when illocutions lead listeners to do things. For instance, turning the lights on after hearing 'It is dark in here' acts as a perlocution.

Speech acts can be realized in different ways in different cultures. Cohen (1996) states that appropriate realization of speech acts depends on two aspects: sociocultural and sociolinguistic ability. Sociocultural ability is related to appropriate choice of strategies to given "(1) the culture involved, (2) the age and sex of the speaker, (3) their social class and occupations, and (4) their roles and status in the interaction," (p. 388) while sociolinguistic ability is concerned with the appropriate choice of linguistic forms. According to Searle (1969), there are universal felicity conditions which constitute the strategies applied in each language to perform illocutionary speech acts. However, empirical studies regarding the universality and culture-specificity of speech acts have shown that they both reflect cultural conventions and universal elements, such as directness. For instance, as far as the cultural values are concerned, the norms of directness level may change depending on the social context. Indirect speech acts are often considered to be more polite than direct ones in English (Blum-Kulka, 1982; Yule, 1996). On the other hand, in some cultures such as Polish, directness may not be considered as a barrier to politeness but rather it might be necessary for rapport-building in social interactions (Wierzbicka, 1991).

In order to understand how speech acts are realized in different languages, the Cross-Cultural Speech Act Realization Project (CCSARP) was conducted in various languages (i.e., Hebrew, Danish, and German) by focusing on request and apology speech acts (Blum-Kulka \& Olshtain, 1984). Since then a large body of cross-cultural pragmatics studies has been conducted across languages by using the same coding scheme or by adapting it (e.g., Lee, 2004; Lu, 2001; Ming-Fang Lin, 2014; Pinto \& Raschio, 2007; Siebold \& Busch, 2015). In the Turkish context, several comparative studies have been conducted with Turkish learners of English to investigate how they realize complaint, apology and request speech acts (e.g., Bikmen \& Marti, 2013; Istifci, 2009; K1lıckaya, 2010). These studies revealed that Turkish 
EFL learners had linguistic means to communicate but their level of politeness was not very satisfactory (Kilickaya, 2010), and they mostly used conventionally indirect forms both in Turkish and English (Mizıkac1, 1991). While most of these studies mentioned both in Turkey and in other countries relied on Discourse Completion Tasks (DCTs) to examine the request speech act patterns, there is a need in the literature for more authentic tasks such as role-plays to support the findings retrieved from DCTs. However, in the present study, our contribution to the field is not the inclusion of a different kind of data collection tool. Instead, we argue that Turkish EFL learners' pragmatic development especially in relation to the use of speech acts should be approached with the framework of conceptual socialization for the following reasons. Even though Turkish learners of English, like most EFL learners, can utter grammatically and phonologically accurate sentences, they do have difficulty in carrying out a conversation with native speakers due to their lack of pragmatic competence. This problem may result from grammar-based teaching, students' focus on the forms and rules of the target language, lack of exposure to native speakers, thus authentic input etc. As a result, while conveying their messages, Turkish EFL may have a tendency to translate sentences from their mother tongue by ignoring the cultural differences in terms of power, distance and directness, all of which affect the level of formality and politeness, and lead to socially inappropriate sentences.

\subsection{Research questions}

The purpose of the study is to investigate Turkish EFL learners' conceptual socialization in terms of their speech acts realization. This study addresses the following research questions:

1. To what extent do higher level Turkish EFL learners differ from native speakers of English in their appropriate realization of request, refusal and acceptance speech acts in;

a. written discourse completion tasks?

b. oral discourse completion tasks?

2. How do Turkish EFL learners differ from native speakers of English in their realization of English and Turkish request, refusal and acceptance speech acts in terms of the level of;

a. formality?

b. politeness?

c. directness?

\section{Method}

\subsection{Participants}

There are two groups of participants in this study: a focal and a baseline group. The focal group consisted of 25 advanced Turkish learners of English studying at a preparatory school of a university in Ankara, Turkey. The participants were chosen randomly from two different B2 level (upperintermediate) classes according to Common European Framework of Reference. The students' age ranged between 18 and 21 and they had been studying English for about six months in this preparatory school.

The baseline group included ten native English speakers (NES), aged 24 - 43, working as English instructors in the same preparatory school in Turkey. Their teaching experience ranged between 2 and 13 years and they were from different BANA countries (e.g., the UK, the USA) with various years of experience working abroad. NESs were included in order to have a baseline of preferred speech act responses. The instructors of the participating learners were selected purposefully as the university is 
the main context, if not the only, where these EFL learners genuinely interact with native speakers and thus their conceptual socialization is facilitated.

\subsection{Instruments}

The data were collected by means of three instruments: a demographic information questionnaire, a written discourse completion task (DCTs) administered both in Turkish and English and an oral DCT (i.e., role-plays). The demographic information section consisted of items inquiring the participants' age, gender, and experiences with learning English.

\subsection{Written DCTs}

Both focal and baseline groups were given a 14-item written DCT where they were expected to write down an appropriate request, refusal or acceptance speech act for each given situation. Each item in the written DCT included a situation and a blank where the participants could write down their responses. The researchers developed the written DCTs by adapting items from various studies (e.g., Blum-Kulka \& Olshtain, 1984; Cohen, 2004; Rose, 1994) so that the given situations would be comprehensible and familiar to the participants' context. DCTs were designed in a way that clearly set the social context and the relationship between the speaker and the interlocutor for the participants. In the following sample test item, request speech acts, such as "Could I have a napkin?" is aimed to be elicited.

Situation 1: You are on an airplane. It is dinner time. The flight attendant sets your food on your tray. You need a napkin. What would you say to the flight attendant?

You:

The DCTs varied on the parameters of social distance and power as they determine the level of directness, politeness and formality in the speech acts the participants would produce (see Table 1).

Table 1. Distribution of the DCT items

\begin{tabular}{lcc}
\hline \multicolumn{1}{c}{ Situation } & Social Status & Item \# \\
\hline A student asks his roommate to clean the kitchen & Equal & 2 \\
A student asks his neighbors to be more quiet & 8 \\
A student refuses to share his notes & Speaker has a lower & 10 \\
You accept to repair a friend's laptop & status & 7 \\
\hline A student asks his professor to give extension & 3 \\
A secretary asks for a permission to leave early & status \\
An employee refuses to work longer & Speaker has a higher \\
You accept to bring your boss' car & 13 \\
\hline A professor asks his student to give presentation earlier & 9 \\
A boss asks his secretary to type letters & Acquaintance \\
A boss refuses to give pay rise & 11 \\
\hline A student asks a school-mate to lend him money & 4 \\
\hline
\end{tabular}




\begin{tabular}{lcc}
\hline You ask for a napkin on the plane & Strangers & 6 \\
You ask a stranger to take your photo & 12 \\
\hline
\end{tabular}

The DCT items were first piloted with two native speakers to see if they were unambiguous and appropriate for the level of participating Turkish EFL students. Based on the feedback given, the items were improved and given to two other native speakers. The process continued until the most appropriate, clear, and unambiguous items were obtained.

For the Turkish version of the DCT instrument, the same task was translated into Turkish by keeping the social factors in mind and the task was given to two different Turkish instructors for feedback. In the case of an ambiguity, the item was revised and given to two other Turkish instructors for feedback. The translated version was backtranslated into English by two Turkish-English bilinguals to see how much it reflected the original English version. Turkish DCTs were given to the learners two weeks after the administration of the English version so that the participants would not recall their answers in English. NESs' responses to the DCTs were used as a baseline to compare with the Turkish learners'. The written DCTs measured the students' realization of speech acts in semi-controlled practice and the Turkish and English versions showed how the same group of learners responded to request speech acts in both languages.

\subsubsection{Oral DCTs (Role-plays)}

Both focal and baseline groups were asked to act out role-plays in pairs requiring them to make and respond to request speech acts by accepting or refusing. Each pair was chosen randomly and given two different role-play tasks so that each participant could utter a request speech act in one of their roles and give a response in the other. Ten role play tasks were adapted from Blum-Kulka and Olshtain (1984) and Boxer and Cohen (2004). The reason for using different role play tasks was to include different social status variables in the study. A sample role-play task for one pair is as follows:

Student A: You are talking to your friend after class. You missed the last class and you want to borrow your friend's notes. How would you ask for this?

Student B: You are talking to your friend after class. He/she missed the last class and wants to borrow your notes. Accept his/her request.

Similar to written DCTs, role-play tasks were piloted with two native speakers to see if they were unambiguous and appropriate to the proficiency level of the students. When there was a problem, the items were improved and given to two other native speakers. The cycle continued until the most appropriate items were obtained. After all the role play tasks were recorded, they were transcribed verbatim by the researchers to be analyzed.

\subsection{Data Analysis}

In this mixed-methods study, first, qualitative data from the written DCTs and audio-recordings of role plays were collected from both focal and baseline groups. Then, they were rated by two different native speakers in order to increase rater reliability. The raters were trained in a calibration session by the researchers to use the criteria. In the grading sheet, the raters were also asked to explain their rea sons for their scores so that their reasoning for deciding if a response is appropriate or not, or why they thought a particular response was formal, impolite or direct would be revealed. Similarly, Turkish EFL learners' responses to Turkish DCTs were rated by two Turkish instructors using the same criteria. The rating scale presented in Table 2 was adapted by the researchers from Boxer and Cohen (2004), BlumKulka and Olshtain (1984) and Aliakbari and Gheitasi (2014). 
Once all the scores were retrieved from the raters, their inter-rater reliability was also calculated for both languages, indicating a high inter-rater reliability for most of the items (e.g., intraclass correlation average measures for formality $r=.87$ for item \#6, for Turkish raters item \# $6 r=.87$ ).

Table 2. Criteria for the ratings of speech acts

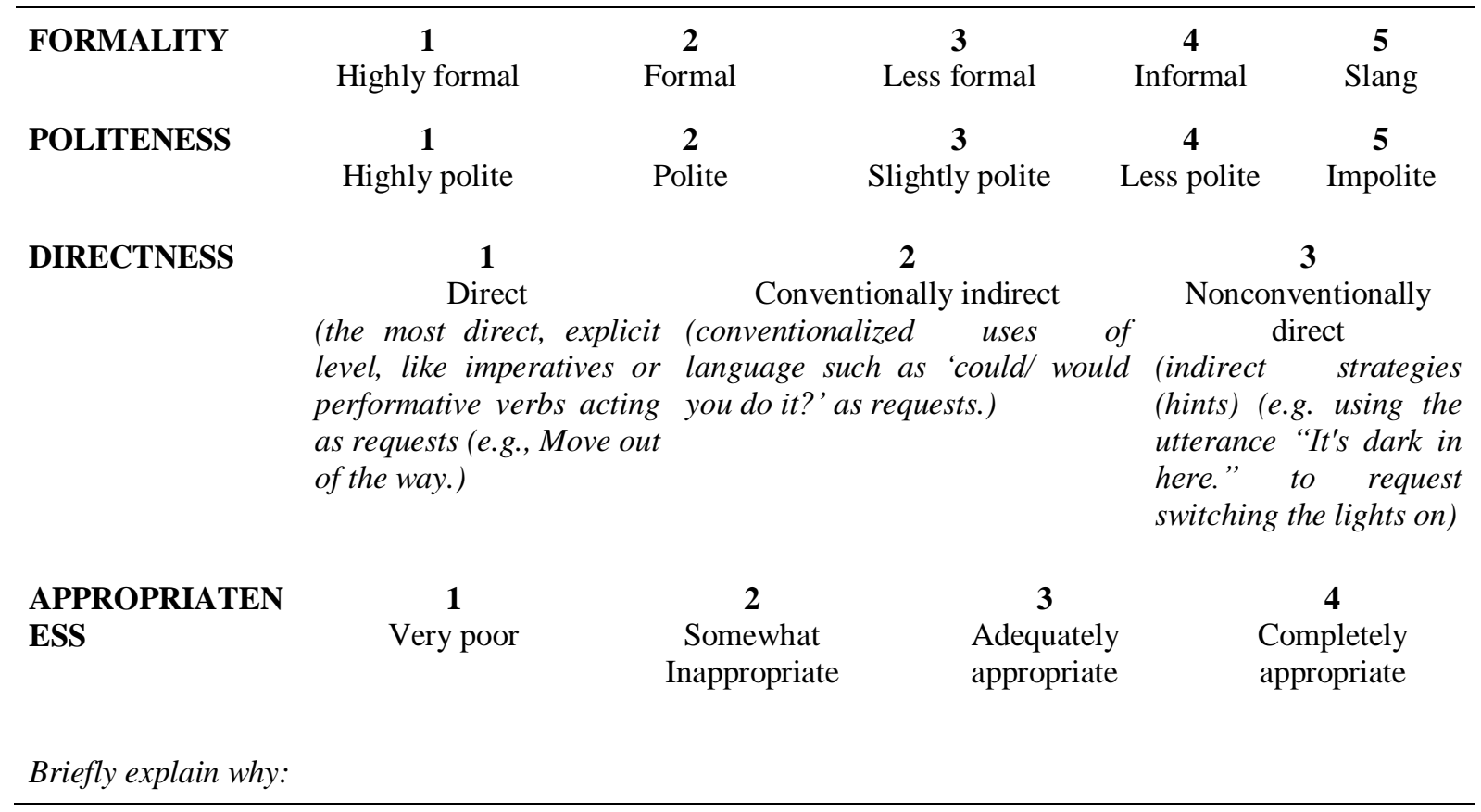

To analyze the data, first, a normality test was conducted for the baseline and focal groups' DCT and role play ratings to see if the data were normally distributed. As the Skewness and Kurtosis values were between -1 and +1 for both tests, two groups' ratings were compared through independent samples ttest for the appropriateness of their request, refusal and acceptance speech acts realization in written and oral production activities.

Second, to answer the second research question, NESs' and Turkish EFL learners' DCT ratings were analyzed descriptively in terms of the level of directness, politeness and formality in the request, refusal and acceptance speech act realization by taking native speaker responses as a baseline to see the similarities and differences between the focal and baseline groups. Also, Turkish EFL learners' responses to DCTs in Turkish were analyzed and descriptively compared with their English responses to see if there was any transfer from their L1.

\section{Results}

\subsection{Comparison of focal and baseline groups in terms of appropriateness}

The data presenting raters' appropriateness scores for both focal and baseline responses to written and oral DCTs were normally distributed (i.e., Skewness and Kurtosis between +1 and -1 ) thus were examined with an independent samples $t$-test (see Table 3). 
Table 3. Appropriateness in Performing Speech Acts

\begin{tabular}{|c|c|c|c|c|c|c|}
\hline \multirow{2}{*}{ Category } & \multirow{2}{*}{ Groups } & & & \multicolumn{3}{|c|}{ t-test } \\
\hline & & $\bar{x}$ & $S D$ & $d f$ & & $t$ \\
\hline \multirow[t]{2}{*}{ Written DCTs } & Focal & 2.66 & .38 & 33 & -8.26 & $.000 *$ \\
\hline & Baseline & 3.71 & .18 & & & \\
\hline \multirow[t]{2}{*}{ Oral DCTs } & Focal & 3.33 & .34 & 33 & -4.17 & $.000 *$ \\
\hline & Baseline & 3.83 & .23 & & & \\
\hline
\end{tabular}

$*_{p} \overline{<.001}$

As seen in Table 3, for the written DCTs, the focal group's level of appropriateness in performing speech acts was lower than the baseline group with a mean difference of -1.05 ( $\overline{\mathrm{x}}$ Focal $=2.66, \mathrm{SD}=$ $.38, \overline{\mathrm{x}}$ Baseline $=3.71, \mathrm{SD}=.18)$ and this difference was statistically significant $(\mathrm{t}(33)=-8.258, p<$ $.001)$. The results were similar for the oral DCTs since Turkish EFL learners' level of appropriateness level was again lower than the NESs' with a mean difference of -.50 . ( $\overline{\mathrm{x}}$ Focal $=3.33$, SD $=.34$; $\overline{\mathrm{x}}$ Baseline $=3.83, \mathrm{SD}=.23)$ and this difference was again statistically significant $(\mathrm{t}(33)=-4.170, p<$ $.001)$.

A follow up test was run as a next step to compare the differences between these two groups in terms of their appropriateness for different speech acts that occurred in written and oral DCTs (i.e., request, accepting and refusing) (see Table 4).

Table 4. Appropriateness for Request, Refusal and Acceptance

\begin{tabular}{|c|c|c|c|c|c|c|c|}
\hline & \multirow{2}{*}{ Speech acts } & \multirow{2}{*}{ Groups } & & & \multicolumn{3}{|c|}{ t-test } \\
\hline & & & $\bar{x}$ & $\mathrm{SD}$ & $\mathrm{df}$ & $\mathrm{t}$ & $p$ \\
\hline & Requests & Focal & 2.58 & .39 & 33 & -9.393 & $.000 * *$ \\
\hline Written & & Baseline & 3.80 & .15 & & & \\
\hline \multirow[t]{5}{*}{ DCTs } & Refusals & Focal & 2.41 & .64 & 33 & -6.143 & $.000 * *$ \\
\hline & & Baseline & 3.72 & .26 & & & \\
\hline & Acceptance & Focal & 3.28 & .76 & 33 & -2.019 & .052 \\
\hline & & Baseline & 3.80 & .42 & & & \\
\hline & Requests & Focal & 3.08 & .90 & 33 & -2.387 & $.023 *$ \\
\hline Oral & & Baseline & 3.80 & .42 & & & \\
\hline \multirow[t]{4}{*}{ DCTS } & Refusals & Focal & 3.12 & .78 & 33 & -2.591 & $.014 *$ \\
\hline & & Baseline & 3.80 & .42 & & & \\
\hline & Acceptance & Focal & 3.80 & .40 & 33 & -.694 & .493 \\
\hline & & Baseline & 3.90 & .31 & & & \\
\hline
\end{tabular}

$* p<.05 * * p<.001$ 
As seen in Table 4, in written DCTs, Turkish EFL learners' level of appropriateness in performing request speech acts was lower than the baseline group's with a mean difference of -1.22 in written DCTs $(\overline{\mathrm{x}}$ Focal requests $=2.58, \mathrm{SD}=.39 ; \overline{\mathrm{x}}$ Baseline requests $=3.80, \mathrm{SD}=.15)$ and this difference was statistically significant $(t(33)=-9.393, p<.001)$. Similar results were observed in the oral DCTs, as the mean difference was $-.72(\overline{\mathrm{x}}$ Focal requests $=3.08, \mathrm{SD}=.90 ; \overline{\mathrm{x}}$ Baseline request $=3.80, \mathrm{SD}=.42)$ being again statistically significant $(\mathrm{t}(33)=-2.387, p<.05)$.

As far as refusals are concerned, the mean difference in the written DCTs was -1.31 , Turkish EFL learners' appropriateness being lower than NES' ( $\overline{\mathrm{x}}$ Focal refusals $=2.41, \mathrm{SD}=.64 ; \overline{\mathrm{x}}$ Baseline refusals $=3.72, \mathrm{SD}=.26)$. Independent samples $t$-test results again indicated a statistically significant difference between these two groups ( $\mathrm{t}(33)=-6.143, p<.001)$. In the oral DCTs, this difference was a bit lower $(\overline{\mathrm{x}}$ Focal refusals $=3.12, \mathrm{SD}=.78 ; \overline{\mathrm{x}}$ Baseline request $=3.80, \mathrm{SD}=.42)$ yet revealing a statistically significant difference again ( $(33)=-2.591, p<.05)$.

Lastly, in comparison of the acceptance speech acts, there was no statistically significant difference between the two groups in both tests as Turkish learners performed very similarly to the NESs in written $(\overline{\mathrm{x}}$ Focal acceptance $=3.28, \mathrm{SD}=.76 ; \overline{\mathrm{x}}$ Baseline acceptance $=3.80, \mathrm{SD}=.42)$ and oral DCTs $(\overline{\mathrm{x}}$ Focal acceptance $=3.80, \mathrm{SD}=.40, \overline{\mathrm{x}}$ Baseline acceptance $=3.90, \mathrm{SD}=.31$ ).

In summary, according to the raters' scores of appropriateness, requests and refusals were problematic for focal group in both written and oral DCTs while they performed similarly to the baseline group in acceptance speech acts. Raters' comments below present the reasons for their scores and explain why the focal group was found less appropriate in their use of speech acts.

Table 5. Common reasons for the focal groups' low scores

\footnotetext{
The speech act sounds like an order.

Lack of 'please' makes it a bit impolite.

Refusing without saying 'sorry' or without providing a reason sounds a bit rude.

Requesting first and then providing the reason is a bit strange.

Requesting without providing a reason makes it less polite.
}

As seen in Table 5, the raters did not make any negative comments about learners' use of grammar or vocabulary but it was mostly about the level of politeness in their production due to the inappropriate use of language. The next section will provide more insight into participants' level of formality, politeness and directness in their use of speech acts.

\subsection{Comparison of Focal and Baseline Groups in terms of Formality, Politeness and Directness in written DCTs}

The raters' assigned scores for formality, politeness and directness of both groups' produced utterances will be presented in terms of frequencies and percentages.

\subsubsection{Requests}

The written DCTs included two items (DCT \# 1 and 2) to elicit requests in a context where the speakers had equal social status (see Table 6). 
Table 6. Ratings for DCT \# 1 and 2

\begin{tabular}{|c|c|c|c|c|c|c|}
\hline DCT & Groups (N) & $\begin{array}{l}\text { Highly Form. } \\
f(\%)\end{array}$ & $\begin{array}{c}\text { Formal } \\
f(\%)\end{array}$ & $\begin{array}{c}\text { Less F. } \\
f(\%)\end{array}$ & $\begin{array}{l}\text { Informal } \\
f(\%)\end{array}$ & $\begin{array}{l}\text { Slang } \\
f(\%)\end{array}$ \\
\hline \multirow{3}{*}{$\begin{array}{l}\text { Formality } \\
\quad \# 1\end{array}$} & Baseline (10) & - & $1(10 \%)$ & $5(50 \%)$ & $4(40 \%)$ & - \\
\hline & Focal (25) & - & $5(20 \%)$ & $7(28 \%)$ & $13(52 \%)$ & - \\
\hline & $\begin{array}{c}\text { Responses in } \\
\text { Turkish (25) }\end{array}$ & - & $1(10 \%)$ & $11(44 \%)$ & $13(52 \%)$ & - \\
\hline \multirow{4}{*}{$\begin{array}{l}\text { Formality } \\
\quad \# 2\end{array}$} & Baseline (10) & - & $8(80 \%)$ & $1(10 \%)$ & $1(10 \%)$ & - \\
\hline & Focal (25) & - & $4(16 \%)$ & $10(40 \%)$ & $11(44 \%)$ & - \\
\hline & $\begin{array}{l}\text { Responses in } \\
\text { Turkish (25) }\end{array}$ & - & $3(12 \%)$ & $14(56 \%)$ & $8(32 \%)$ & - \\
\hline & & Highly Polite & Polite & Slightly P. & Less P. & Impolite \\
\hline \multirow{3}{*}{$\begin{array}{l}\text { Politeness } \\
\quad \# 1\end{array}$} & Baseline (10) & - & $8(80 \%)$ & $2(20 \%)$ & - & - \\
\hline & Focal (25) & - & $9(36 \%)$ & $4(16 \%)$ & $9(36 \%)$ & $3(12 \%)$ \\
\hline & $\begin{array}{l}\text { Responses in } \\
\text { Turkish (25) }\end{array}$ & - & $9(36 \%)$ & $12(48 \%)$ & $3(12 \%)$ & $1(4 \%)$ \\
\hline \multirow{4}{*}{$\begin{array}{l}\text { Politeness } \\
\quad \text { \# } 2\end{array}$} & Baseline (10) & $2(20 \%)$ & $6(60 \%)$ & $2(20 \%)$ & - & - \\
\hline & Focal (25) & - & $3(12 \%)$ & $8(32 \%)$ & $9(36 \%)$ & $5(20 \%)$ \\
\hline & $\begin{array}{l}\text { Responses in } \\
\text { Turkish (25) }\end{array}$ & - & $12(48 \%)$ & $9(36 \%)$ & $4(32 \%)$ & - \\
\hline & & Direct & Conventi & y Indirect & Noncol & irect \\
\hline \multirow{3}{*}{$\begin{array}{l}\text { Directn. } \\
\quad \# 1\end{array}$} & Baseline (10) & $1(10 \%)$ & \multicolumn{2}{|c|}{$9(90 \%)$} & \multicolumn{2}{|c|}{ - } \\
\hline & Focal (25) & $5(20 \%)$ & \multicolumn{2}{|c|}{$20(80 \%)$} & \multicolumn{2}{|c|}{-} \\
\hline & $\begin{array}{l}\text { Responses in } \\
\text { Turkish (25) }\end{array}$ & $9(36 \%)$ & \multicolumn{2}{|c|}{$16(64 \%)$} & \multicolumn{2}{|c|}{-} \\
\hline \multirow{3}{*}{$\begin{array}{l}\text { Directn. } \\
\quad \# 2\end{array}$} & Baseline (10) & $1(10 \%)$ & \multicolumn{2}{|c|}{$9(90 \%)$} & \multicolumn{2}{|c|}{ - } \\
\hline & Focal (25) & $5(20 \%)$ & \multicolumn{2}{|c|}{$20(80 \%)$} & \multicolumn{2}{|c|}{-} \\
\hline & $\begin{array}{l}\text { Responses in } \\
\text { Turkish (25) }\end{array}$ & $5(20 \%)$ & \multicolumn{2}{|c|}{$17(68 \%)$} & \multicolumn{2}{|c|}{$3(12 \%)$} \\
\hline
\end{tabular}

When the formality level for DCT \# 1 is concerned, the baseline group mostly adopted informal (40\%) and less formal (50\%) attitude and the focal group performed similarly both in their Turkish (52\% informal) and English responses (52\% informal). As for the formality level for DCT \# 2, NESs mostly $(80 \%)$ adopted a formal way while only $16 \%$ of the students were at a formal level.

In terms of the level of politeness, most NESs $(80 \%)$ used a polite way to make a request in both situations, while in the focal group only $36 \%$ in DCT \#1 and $12 \%$ in DCT \#2 used a polite way of requesting. When EFL learners' responses in Turkish and English were compared, about half of them employed less polite and impolite requests in English, while more preferred to use polite (48\% in DCT \# 2) and slightly polite requests (48\% in DCT \# 1) in Turkish. For instance, Turkish speech act for DCT \# 1, "Mutfagi temizler misin?" meaning "Could you clean the kitchen?" was found to be polite in Turkish. However, when most of the students used expressions such as "Dude can you clean the kitchen?" it was found to be less polite in English. Instead, one of the common responses that was reported as polite from native speakers was "Would you mind cleaning up please as I have friends coming around soon?"

As for directness, both baseline (90\%) and focal (80\%) groups mostly preferred to use conventionally indirect requests both in DCT \# 1 and 2. Turkish EFL learners' Turkish responses showed similarity to their English responses with 64\% in DCT \# 1, 68\% in DCT \# 2. However, there were a few responses 
more direct in Turkish for DCT \# 1 (i.e., "Eger isin yoksa, mutfaga bi el at," meaning "If you don't have anything to do, start cleaning the kitchen.”).

As far as requests by a person of lower status is concerned, there were again two items in the written DCTs, DCT \# 5 and 7 (see Table 7).

Table 7. Ratings for DCT \# 5 and 7

\begin{tabular}{|c|c|c|c|c|c|c|}
\hline DCT & Groups $(\mathrm{N})$ & $\begin{array}{l}\text { Highly Form. } \\
\qquad f(\%)\end{array}$ & $\begin{array}{l}\text { Formal } \\
f(\%)\end{array}$ & $\begin{array}{c}\text { Less F. } \\
f(\%)\end{array}$ & $\begin{array}{c}\text { Informal } \\
f(\%)\end{array}$ & $\begin{array}{l}\text { Slang } \\
f(\%)\end{array}$ \\
\hline \multirow{3}{*}{$\begin{array}{c}\text { Formality \# } \\
5\end{array}$} & Baseline (10) & - & $9(90 \%)$ & $1(10 \%)$ & - & - \\
\hline & Focal (25) & - & $9(36 \%)$ & $12(48 \%)$ & $4(16 \%)$ & - \\
\hline & $\begin{array}{l}\text { Responses in } \\
\text { Turkish (25) }\end{array}$ & - & $13(52 \%)$ & $12(48 \%)$ & - & - \\
\hline \multirow{4}{*}{$\begin{array}{l}\text { Formality } \\
\quad \# 7\end{array}$} & Baseline (10) & $2(20 \%)$ & $8(80 \%)$ & - & - & - \\
\hline & Focal (25) & - & $9(36 \%)$ & $14(56 \%)$ & $2(8 \%)$ & - \\
\hline & $\begin{array}{l}\text { Responses in } \\
\text { Turkish (25) }\end{array}$ & - & $12(48 \%)$ & $13(52 \%)$ & - & - \\
\hline & & Highly Polite & Polite & Slightly P. & Less $\mathrm{P}$. & Impolite \\
\hline \multirow{3}{*}{$\begin{array}{l}\text { Politeness } \\
\quad \# 5\end{array}$} & Baseline (10) & $1(10 \%)$ & $9(90 \%)$ & - & - & - \\
\hline & Focal (25) & - & $9(36 \%)$ & $12(48 \%)$ & $4(16 \%)$ & - \\
\hline & $\begin{array}{l}\text { Responses in } \\
\text { Turkish (25) }\end{array}$ & - & $22(88 \%)$ & $3(12 \%)$ & - & - \\
\hline \multirow{4}{*}{$\begin{array}{l}\text { Politeness } \\
\quad \# 7\end{array}$} & Baseline (10) & $3(30 \%)$ & $7(70 \%)$ & - & - & - \\
\hline & Focal (25) & - & $12(48 \%)$ & $11(44 \%)$ & $2(8 \%)$ & - \\
\hline & $\begin{array}{l}\text { Responses in } \\
\text { Turkish (25) }\end{array}$ & - & $18(72 \%)$ & $5(20 \%)$ & $2(8 \%)$ & - \\
\hline & & Direct & Conventio & y Indirect & Nonce & Direct \\
\hline \multirow{3}{*}{$\begin{array}{c}\text { Directness \# } \\
5\end{array}$} & Baseline (10) & $1(10 \%)$ & & & & \\
\hline & Focal (25) & $1(4 \%)$ & 24 & & & \\
\hline & $\begin{array}{l}\text { Responses in } \\
\text { Turkish (25) }\end{array}$ & $1(4 \%)$ & & & & \\
\hline \multirow{3}{*}{$\begin{array}{c}\text { Directness \# } \\
7\end{array}$} & Baseline (10) & - & 10( & & & \\
\hline & Focal (25) & - & 25 & & & \\
\hline & $\begin{array}{l}\text { Responses in } \\
\text { Turkish (25) }\end{array}$ & $2(8 \%)$ & 23 & & & \\
\hline
\end{tabular}

As seen in Table 7, while most NESs (90\% in DCT \# 5; 80\% in DCT \# 7) used formal requests, only $36 \%$ of the EFL learners were at the same level in both items. As for politeness, NESs employed a polite attitude to make a request (90\% and 70\% in DCT \# 5 and 7, respectively), while $36 \%$ in DCT \# 5 and 
$48 \%$ of the focal group in DCT \# 7 were at the same politeness level. In terms of directness, baseline group used conventionally indirect requests, and focal group performed similarly.

When the learners' English and Turkish responses were compared, EFL learners showed similar levels of formality by using formal and less formal requests with few responses being informal in English. In terms of politeness, majority of Turkish responses were at the polite level, however, their English responses were slightly polite. Learners performed similarly at the level of directness in both languages. For instance, "Odevimi henuz tamamlayamadim. Ek sure vermeniz mumkun mu?" meaning "I haven't finished my assignment yet. Would it be possible to give extension?" was found to be polite and conventionally indirect in Turkish. On the other hand, "Professor, could you give me extra time because I am very busy? " was found to be less polite as it lacks 'please' and reason is provided after the request. DCT \# 9 and 11 were the items measuring requests by a person of higher status.

Table 8. Ratings for DCT \# 9 and 11

\begin{tabular}{|c|c|c|c|c|c|c|}
\hline DCT & Groups (N) & $\begin{array}{c}\text { Highly Form. } \\
\qquad f(\%)\end{array}$ & $\begin{array}{l}\text { Formal } \\
f(\%)\end{array}$ & $\begin{array}{l}\text { Less F. } \\
f(\%)\end{array}$ & $\begin{array}{c}\text { Informal } \\
f(\%)\end{array}$ & $\begin{array}{l}\text { Slang } \\
f(\%)\end{array}$ \\
\hline \multirow{3}{*}{$\begin{array}{c}\text { Formality \# } \\
9\end{array}$} & Baseline (10) & - & $4(40 \%)$ & $6(60 \%)$ & - & - \\
\hline & Focal (25) & - & $6(24 \%)$ & $9(36 \%)$ & $10(40 \%)$ & - \\
\hline & $\begin{array}{l}\text { Responses in } \\
\text { Turkish (25) }\end{array}$ & - & $2(8 \%)$ & $19(76 \%)$ & $4(16 \%)$ & - \\
\hline \multirow{3}{*}{$\begin{array}{l}\text { Formality } \\
\quad \# 11\end{array}$} & Baseline (10) & $1(10 \%)$ & $6(60 \%)$ & $3(30 \%)$ & - & - \\
\hline & Focal (25) & - & $6(24 \%)$ & $11(44 \%)$ & $7(28 \%)$ & $1(4 \%)$ \\
\hline & $\begin{array}{l}\text { Responses in } \\
\text { Turkish (25) }\end{array}$ & - & $4(16 \%)$ & $14(56 \%)$ & $7(28 \%)$ & - \\
\hline DCT & & Highly Polite & Polite & Slightly P. & Less P. & Impolite \\
\hline \multirow{3}{*}{$\begin{array}{l}\text { Politeness } \\
\quad \# 9\end{array}$} & Baseline (10) & $2(20 \%)$ & $8(80 \%)$ & - & - & - \\
\hline & Focal (25) & - & $10(40 \%)$ & $9(36 \%)$ & $4(16 \%)$ & $2(8 \%)$ \\
\hline & $\begin{array}{l}\text { Responses in } \\
\text { Turkish (25) }\end{array}$ & - & $7(28 \%)$ & $12(48 \%)$ & $6(24 \%)$ & - \\
\hline \multirow{3}{*}{$\begin{array}{l}\text { Politeness } \\
\quad \# 11\end{array}$} & Baseline (10) & $3(30 \%)$ & $6(60 \%)$ & $1(10 \%)$ & - & - \\
\hline & Focal (25) & - & $8(32 \%)$ & $7(28 \%)$ & $4(16 \%)$ & $5(20 \%)$ \\
\hline & $\begin{array}{l}\text { Responses in } \\
\text { Turkish (25) }\end{array}$ & - & $9(36 \%)$ & $7(28 \%)$ & $5(20 \%)$ & $1(4 \%)$ \\
\hline DCT & & Direct & Conventi & lly Indirect & Nonce & Direct \\
\hline \multirow{3}{*}{$\begin{array}{l}\text { Directness } \\
\quad \# 9\end{array}$} & Baseline (10) & $1(10 \%)$ & \multicolumn{2}{|c|}{$9(90 \%)$} & \multicolumn{2}{|c|}{ - } \\
\hline & Focal (25) & $6(24 \%)$ & \multicolumn{2}{|c|}{$19(76 \%)$} & \multicolumn{2}{|c|}{-} \\
\hline & $\begin{array}{l}\text { Responses in } \\
\text { Turkish (25) }\end{array}$ & $12(48 \%)$ & \multicolumn{2}{|c|}{$9(36 \%)$} & \multicolumn{2}{|c|}{-} \\
\hline \multirow{3}{*}{$\begin{array}{l}\text { Directness } \\
\quad \# 11\end{array}$} & Baseline (10) & $1(10 \%)$ & \multicolumn{2}{|c|}{$9(90 \%)$} & \multicolumn{2}{|c|}{ - } \\
\hline & Focal (25) & $4(16 \%)$ & \multicolumn{2}{|c|}{$21(84 \%)$} & \multicolumn{2}{|c|}{ - } \\
\hline & $\begin{array}{l}\text { Responses in } \\
\text { Turkish (25) }\end{array}$ & $11(44 \%)$ & \multicolumn{2}{|c|}{$13(52 \%)$} & \multicolumn{2}{|c|}{$1(4 \%)$} \\
\hline
\end{tabular}


The baseline group mostly employed a 'formal' ( $40 \%$ for DCT \#9) and 'less formal' ( $60 \%$ for DCT \# 11) way of requesting in this category. More than half of the learners (24\% formal, $36 \%$ less formal in DCT \# 9; $24 \%$ formal, $44 \%$ less formal in DCT \# 11) showed similarity while about 30 - $40 \%$ of them preferred to be informal. In terms of politeness, while almost all the NESs used a polite form of request, about $60 \%$ of the focal group failed to reach the same level of politeness. As for the level of directness, both groups mostly adopted conventionally indirect way to make the request with a few Turkish learners being more direct.

Focal group preferred similar levels of formality in their Turkish and English responses by using formal, less formal and informal requests when a request is made by a person of higher social status. As for politeness, responses showed variety in both languages between polite and impolite and their ratings were similar in English and Turkish. In terms of directness, EFL learners (48 \% in DCT \# 9 and $44 \%$ in DCT \# 11) were more direct in their Turkish responses than English. For instance, for DCT \# 9, in Turkish "Hazirsan, sunumunu bir kac gun once yapmani isterim," meaning "I would like you to give your presentation a few days earlier if you are ready." was one of the common direct responses. However, in English their use of indirect ones such as "Can you give your presentation a few days earlier?" were more common.

Requests to acquaintances was measured with DCT \# 4 (see Table 9).

Table 9. Ratings for DCT \# 4

\begin{tabular}{|c|c|c|c|c|c|c|}
\hline DCT & Groups (N) & $\begin{array}{l}\text { Highly Form. } \\
\qquad f(\%)\end{array}$ & $\begin{array}{l}\text { Formal } \\
f(\%)\end{array}$ & $\begin{array}{c}\text { Less F. } \\
f(\%)\end{array}$ & $\begin{array}{c}\text { Informal } \\
f(\%)\end{array}$ & $\begin{array}{l}\text { Slang } \\
f(\%)\end{array}$ \\
\hline Formality & Baseline (10) & - & $7(70 \%)$ & $3(30 \%)$ & - & - \\
\hline \multirow[t]{3}{*}{$\# 4$} & Focal (25) & - & - & $14(56 \%)$ & $9(36 \%)$ & $2(8 \%)$ \\
\hline & $\begin{array}{l}\text { Responses in } \\
\text { Turkish (25) }\end{array}$ & - & $1(4 \%)$ & $16(64 \%)$ & $6(24 \%)$ & $2(8 \%)$ \\
\hline & & Highly Polite & Polite & Slightly P. & Less P. & Impolite \\
\hline Politeness & Baseline (10) & $3(30 \%)$ & $7(70 \%)$ & - & - & - \\
\hline \multirow[t]{3}{*}{$\# 4$} & Focal (25) & - & $6(24 \%)$ & $10(40 \%)$ & $4(16 \%)$ & $4(16 \%)$ \\
\hline & $\begin{array}{l}\text { Responses in } \\
\text { Turkish (25) }\end{array}$ & - & $15(60 \%)$ & $7(28 \%)$ & $3(12 \%)$ & - \\
\hline & & Direct & \multicolumn{2}{|c|}{ Conventionally Indirect } & \multicolumn{2}{|c|}{ Noncon. Direct } \\
\hline Directn. & Baseline (10) & - & \multicolumn{2}{|c|}{$10(100 \%)$} & \multicolumn{2}{|c|}{-} \\
\hline \multirow[t]{2}{*}{$\# 4$} & Focal (25) & - & \multicolumn{2}{|c|}{$25(100 \%)$} & \multicolumn{2}{|c|}{ - } \\
\hline & $\begin{array}{l}\text { Responses in } \\
\text { Turkish (25) }\end{array}$ & $2(8 \%)$ & \multicolumn{2}{|c|}{$22(88 \%)$} & \multicolumn{2}{|c|}{$1(4 \%)$} \\
\hline
\end{tabular}

When making a request to an acquaintance, the majority of the baseline group (70\%) used formal while only some (30\%) used less formal requests. $56 \%$ of the focal group employed a less formal way of requesting but $44 \%$ of them used informal requests. While NESs were quite polite in their requests, only $24 \%$ of the learners were at the same level of politeness. There was not any difference in the level of directness between the two groups. 
EFL learners showed similar levels of formality in English and Turkish by using mostly less formal and informal requests when talking to acquaintances. As for the level of politeness, they also showed similarity by preferring polite, slightly polite and less polite requests. However, there were more students' using polite requests in Turkish than English. EFL learners' English and Turkish responses were similar in the use of conventionally indirect requests. For instance, the following response to DCT \# 4 was found polite in Turkish: "Paramı evde unutmusum, bana biraz borc verebilir misin? Yarın getiririm." meaning "I left my wallet at home, can you lend me some money? I will bring it tomorrow." However, the following response in English was rated as slightly polite as it lacks please and request comes before the reason: "Can you give me some money? I forgot to take money from my parents but I have to go home." One of the appropriate response from native speakers was "Could you do me a favor, Ineed to get home and realized I don't have any cash. Could you lend me some until tomorrow please?"

DCT \# 12 and 6 measured requests to strangers (see Table 10).

Table 10. Ratings for DCT \# 12 and 6

\begin{tabular}{|c|c|c|c|c|c|c|}
\hline DCT & Groups (N) & $\begin{array}{l}\text { Highly Form. } \\
\qquad f(\%)\end{array}$ & $\begin{array}{l}\text { Formal } \\
f(\%)\end{array}$ & $\begin{array}{l}\text { Less F. } \\
f(\%)\end{array}$ & $\begin{array}{c}\text { Informal } \\
f(\%)\end{array}$ & $\begin{array}{l}\text { Slang } \\
f(\%)\end{array}$ \\
\hline \multirow{3}{*}{$\begin{array}{l}\text { Formality } \\
\quad \# 12\end{array}$} & Baseline (10) & - & $5(50 \%)$ & $5(50 \%)$ & - & - \\
\hline & Focal (25) & - & $11(44 \%)$ & $8(32 \%)$ & $6(24 \%)$ & - \\
\hline & TR (25) & - & $21(84 \%)$ & $4(16 \%)$ & - & - \\
\hline \multirow{4}{*}{$\begin{array}{l}\text { Formality } \\
\quad \# 6\end{array}$} & Baseline (10) & $1(10 \%)$ & $7(70 \%)$ & $2(20 \%)$ & - & - \\
\hline & Focal (25) & - & $14(56 \%)$ & $10(40 \%)$ & $1(4 \%)$ & - \\
\hline & TR (25) & - & $17(68 \%)$ & $8(32 \%)$ & - & - \\
\hline & & Highly Polite & Polite & Slightly P. & Less $\mathrm{P}$. & Impolite \\
\hline \multirow{3}{*}{$\begin{array}{l}\text { Politeness } \\
\quad \# 12\end{array}$} & Baseline (10) & - & $10(100 \%)$ & - & - & - \\
\hline & Focal (25) & - & $15(60 \%)$ & $8(32 \%)$ & $2(8 \%)$ & - \\
\hline & TR (25) & - & $21(84 \%)$ & $4(16 \%)$ & - & - \\
\hline \multirow{4}{*}{$\begin{array}{l}\text { Politeness } \\
\quad \# 6\end{array}$} & Baseline (10) & $2(20 \%)$ & $8(80 \%)$ & - & - & - \\
\hline & Focal (25) & - & $13(52 \%)$ & $10(40 \%)$ & $1(4 \%)$ & $1(4 \%)$ \\
\hline & TR (25) & - & $22(88 \%)$ & $3(12 \%)$ & - & - \\
\hline & & Direct & Conventic & ly Indirect & Noncol & Direct \\
\hline \multirow{3}{*}{$\begin{array}{l}\text { Directness } \\
\quad \# 12\end{array}$} & Baseline (10) & - & \multicolumn{2}{|c|}{$10(100 \%)$} & \multicolumn{2}{|c|}{-} \\
\hline & Focal (25) & - & \multicolumn{2}{|c|}{$25(100 \%)$} & \multicolumn{2}{|c|}{ - } \\
\hline & TR (25) & - & \multicolumn{2}{|c|}{$25(100 \%)$} & \multicolumn{2}{|c|}{-} \\
\hline \multirow{3}{*}{$\begin{array}{l}\text { Directness } \\
\quad \# 6\end{array}$} & Baseline (10) & - & \multicolumn{2}{|c|}{$10(100 \%)$} & \multicolumn{2}{|c|}{-} \\
\hline & Focal (25) & $1(4 \%)$ & \multicolumn{2}{|c|}{$24(96 \%)$} & \multicolumn{2}{|c|}{ - } \\
\hline & TR (25) & $1(4 \%)$ & \multicolumn{2}{|c|}{$24(96 \%)$} & \multicolumn{2}{|c|}{-} \\
\hline
\end{tabular}


As presented in Table 10, the baseline group used formal (50\%) and less formal (50\%) requests in DCT \# 12, while the focal group also used a similar level of formality with only $24 \%$ of them being informal. In DCT \# 6, most NESs used a formal language to make request with few being less formal and $56 \%$ of the students showed a similar level of formality by using formal requests. In terms of politeness, NESs again used a polite way to make a request. About $60 \%$ of the learners adopted a similar way while $40 \%$ of them were less polite. Both groups used the same level of directness.

When Turkish learners requested from strangers, their level of formality and politeness were higher in Turkish than English. However, directness level was the same in both languages. For instance, the following response was found to be polite and formal in Turkish: "Pardon, fotografimizl cekebilir misiniz?" meaning "Sorry, could you take our photo?" The translated version was accepted as appropriate in NESs' responses and more than half of the students did perform similarly. As Turkish is an agglutinating language, the suffix 'misiniz', which states second person plural pronoun, can be translated as 'can' and 'could.' Second person plural pronoun is used to address strangers and people with higher social status to show respect and make the language formal. However, when students used the following expression in English, they were found less polite: "Can you take our photo?"

\subsubsection{Refusing Requests}

DCT \# 11 measured refusals in equal social status (see Table 11).

Table 11. Ratings for DCT \# 8

\begin{tabular}{|c|c|c|c|c|c|c|}
\hline DCT & $\begin{array}{c}\text { Groups } \\
(\mathrm{N})\end{array}$ & $\begin{array}{l}\text { Highly Form. } \\
\qquad f(\%)\end{array}$ & $\begin{array}{l}\text { Formal } \\
f(\%)\end{array}$ & $\begin{array}{c}\text { Less F. } \\
f(\%)\end{array}$ & $\begin{array}{c}\text { Informal } \\
f(\%)\end{array}$ & $\begin{array}{l}\text { Slang } \\
f(\%)\end{array}$ \\
\hline Formality & Baseline (10) & - & $2(20 \%)$ & $6(60 \%)$ & $2(20 \%)$ & - \\
\hline \multirow[t]{3}{*}{$\# 8$} & Focal (25) & - & $5(20 \%)$ & $4(16 \%)$ & $15(60 \%)$ & $1(4 \%)$ \\
\hline & $\begin{array}{l}\text { Responses in } \\
\text { Turkish (25) }\end{array}$ & - & $2(8 \%)$ & $15(60 \%)$ & $8(32 \%)$ & - \\
\hline & & Highly Polite & Polite & Slightly P. & Less P. & Impolite \\
\hline Politeness & Baseline (10) & - & $10(100 \%)$ & - & - & - \\
\hline \multirow[t]{3}{*}{$\# 8$} & Focal (25) & - & $10(40 \%)$ & $2(8 \%)$ & $7(28 \%)$ & $6(24 \%)$ \\
\hline & $\begin{array}{l}\text { Responses in } \\
\text { Turkish (25) }\end{array}$ & - & $7(28 \%)$ & $9(36 \%)$ & $9(36 \%)$ & - \\
\hline & & Direct & \multicolumn{2}{|c|}{ Conventionally Indirect } & \multicolumn{2}{|c|}{ Noncon. Direct } \\
\hline Directn. & Baseline (10) & $1(10 \%)$ & \multicolumn{2}{|c|}{$3(30 \%)$} & \multicolumn{2}{|c|}{$6(60 \%)$} \\
\hline \multirow[t]{2}{*}{$\# 8$} & Focal (25) & $11(44 \%)$ & \multicolumn{2}{|c|}{$9(36 \%)$} & \multicolumn{2}{|c|}{$4(16 \%)$} \\
\hline & $\begin{array}{l}\text { Responses in } \\
\text { Turkish (25) }\end{array}$ & $11(44 \%)$ & \multicolumn{2}{|c|}{$3(12 \%)$} & \multicolumn{2}{|c|}{$11(44 \%)$} \\
\hline
\end{tabular}

For the present item, while $60 \%$ of the baseline group used less formal refusals, $60 \%$ of the focal group used informal ones. As for politeness, while all the native speakers employed a polite way to refuse, $60 \%$ of the learners did not reach the same level of politeness. Directness of the both participant groups were not the same in this context. More than half of the baseline group used conventionally 
indirect way which requires speakers to use hints instead of directly refusing. However, $44 \%$ of the focal group was quite direct in their refusals.

When comparing the responses in two languages, learners' refusal speech acts use ranged from formal to informal. However, while more speech acts (60\%) were considered less formal in Turkish, majority (60\%) was found to be informal in English. Ratings for the level of politeness and directness showed variety in the speech acts use, as well. However, this variety showed similarity for Turkish and English. To exemplify the different levels of directness, the direct ones stated "Sorry, I can't share my notes." both in Turkish and English. Indirect ones stated "Sorry, I need them tonight," "I don't have my notes with me," "My handwriting is bad."

Refusing inferiors was measured with DCT \# 12 (see Table 12).

Table 12. Ratings for DCT \# 14

\begin{tabular}{|c|c|c|c|c|c|c|}
\hline DCT & Groups $(\mathrm{N})$ & $\begin{array}{l}\text { Highly Form. } \\
\qquad f(\%)\end{array}$ & $\begin{array}{l}\text { Formal } \\
f(\%)\end{array}$ & $\begin{array}{c}\text { Less F. } \\
f(\%)\end{array}$ & $\begin{array}{c}\text { Informal } \\
f(\%)\end{array}$ & $\begin{array}{l}\text { Slang } \\
f(\%)\end{array}$ \\
\hline Formality & Baseline (10) & - & $5(50 \%)$ & $5(50 \%)$ & - & - \\
\hline \multirow[t]{3}{*}{ \# 14} & Focal (25) & - & $4(16 \%)$ & $13(52 \%)$ & $8(32 \%)$ & - \\
\hline & $\begin{array}{l}\text { Responses in } \\
\text { Turkish (25) }\end{array}$ & - & $2(8 \%)$ & $18(72 \%)$ & $5(20 \%)$ & - \\
\hline & & Highly Polite & Polite & Slightly P. & Less P. & Impolite \\
\hline Politeness & Baseline (10) & - & $4(40 \%)$ & $5(50 \%)$ & $1(10 \%)$ & - \\
\hline \multirow[t]{3}{*}{ \# 14} & Focal (25) & - & $8(32 \%)$ & $6(24 \%)$ & $9(36 \%)$ & $2(8 \%)$ \\
\hline & $\begin{array}{l}\text { Responses in } \\
\text { Turkish (25) }\end{array}$ & - & $8(32 \%)$ & $11(44 \%)$ & $6(24 \%)$ & - \\
\hline & & Direct & \multicolumn{2}{|c|}{ Conventionally Indirect } & \multicolumn{2}{|c|}{ Noncon. Direct } \\
\hline \multirow{3}{*}{$\begin{array}{c}\text { Directn. } \\
\text { \# } 14\end{array}$} & Baseline (10) & $1(10 \%)$ & \multicolumn{2}{|c|}{$9(90 \%)$} & \multicolumn{2}{|c|}{-} \\
\hline & Focal (25) & $5(20 \%)$ & \multicolumn{2}{|c|}{$20(80 \%)$} & \multicolumn{2}{|c|}{-} \\
\hline & $\begin{array}{l}\text { Responses in } \\
\text { Turkish (25) }\end{array}$ & $5(20 \%)$ & \multicolumn{2}{|c|}{$17(68 \%)$} & \multicolumn{2}{|c|}{$3(12 \%)$} \\
\hline
\end{tabular}

As the Table 12 shows, the baseline group used formal and less formal refusals and $68 \%$ of the focal group used the same level of formality. NESs were more polite in their use of refusal speech acts (40\% polite and $50 \%$ slightly polite) than the focal group (32\% polite and $24 \%$ slightly polite). As for the level of directness, two groups were mostly conventionally indirect.

When the Turkish learners' responses in English and Turkish were compared, majority of the Turkish learners' responses were less formal in both Turkish and English. Similar level of politeness was revealed in two languages with a few responses in English being less polite. Level of directness was also similar in both languages. For instance, one of the most common responses in Turkish was "Uzgunum bu siralar pek mumkun gronmuyor." meaning "Sorry, it doesn't seem possible these days." Turkish EFL learners used the same response in English as well. Additionally, native speaker responses were quite similar: "I am sorry but right now it's not financially possible." 
Refusing superiors was measured with DCT \# 3 (see Table 13).

Table 13. Ratings for DCT \# 3

\begin{tabular}{|c|c|c|c|c|c|c|}
\hline DCT & Groups (N) & $\begin{array}{c}\text { Highly Form. } \\
f(\%)\end{array}$ & $\begin{array}{l}\text { Formal } \\
f(\%)\end{array}$ & $\begin{array}{l}\text { Less F. } \\
f(\%)\end{array}$ & $\begin{array}{l}\text { Informal } \\
f(\%)\end{array}$ & $\begin{array}{l}\text { Slang } \\
f(\%)\end{array}$ \\
\hline Formality & Baseline (10) & - & $2(20 \%)$ & $5(50 \%)$ & $3(30 \%)$ & - \\
\hline \multirow[t]{3}{*}{ \# 3} & Focal (25) & - & $3(12 \%)$ & $17(68 \%)$ & $5(20 \%)$ & - \\
\hline & $\begin{array}{l}\text { Responses in } \\
\text { Turkish (25) }\end{array}$ & - & $4(16 \%)$ & $16(64 \%)$ & $4(16 \%)$ & $1(4 \%)$ \\
\hline & & Highly Polite & Polite & Slightly P. & Less $P$. & Impolite \\
\hline Politeness & Baseline (10) & $2(20 \%)$ & $5(50 \%)$ & $3(30 \%)$ & - & - \\
\hline \multirow[t]{3}{*}{$\# 3$} & Focal (25) & - & $5(20 \%)$ & $14(56 \%)$ & $5(20 \%)$ & $1(4 \%)$ \\
\hline & $\begin{array}{l}\text { Responses in } \\
\text { Turkish (25) }\end{array}$ & - & $9(36 \%)$ & $13(52 \%)$ & $2(8 \%)$ & $1(4 \%)$ \\
\hline & & Direct & \multicolumn{2}{|c|}{ Conventionally Indirect } & \multicolumn{2}{|c|}{ Noncon. Direct } \\
\hline Directn. & Baseline (10) & $1(10 \%)$ & \multicolumn{2}{|c|}{$9(90 \%)$} & \multicolumn{2}{|c|}{-} \\
\hline \multirow[t]{2}{*}{ \# 3} & Focal (25) & $1(4 \%)$ & \multicolumn{2}{|c|}{$24(96 \%)$} & \multicolumn{2}{|c|}{-} \\
\hline & $\begin{array}{l}\text { Responses in } \\
\text { Turkish (25) }\end{array}$ & $10(40 \%)$ & \multicolumn{2}{|c|}{$12(48 \%)$} & \multicolumn{2}{|c|}{$3(12 \%)$} \\
\hline
\end{tabular}

In this item, both groups showed similar levels of formality, which ranged from formal to informal. In terms of politeness, $70 \%$ of the NESs adopted a polite and slightly polite way to refuse. Majority of the learners (56\%) used slightly polite refusals. In both groups, conventionally indirect level of refusing was observed.

The level of formality and politeness was similar in focal group's Turkish and English responses with the majority of the answers being slightly polite and less formal. However, for the level of directness, about half of the Turkish responses were more direct than English ones, and there were also few conventionally indirect refusals in Turkish. One of the observations made in this item was that most NESs made a request to leave early instead of refusing to work longer. Some students also responded similarly. To exemplify, Turkish EFL learners responded in Turkish as "Yarın devam etsek uygun olur mu?" meaning "Would it be possible to work on tomorrow?" They used similar expressions in English.

\subsubsection{Accepting Requests}

There were two items where participants are expected to accept requests from a person of equal (DCT \# 10) and higher social status (DCT \# 13). 
Table 14. Ratings for DCT \#10 \& 13

\begin{tabular}{|c|c|c|c|c|c|c|}
\hline DCT & Groups (N) & $\begin{array}{l}\text { Highly Form. } \\
\qquad f(\%)\end{array}$ & $\begin{array}{l}\text { Formal } \\
f(\%)\end{array}$ & $\begin{array}{l}\text { Less F. } \\
f(\%)\end{array}$ & $\begin{array}{l}\text { Informal } \\
f(\%)\end{array}$ & $\begin{array}{l}\text { Slang } \\
f(\%)\end{array}$ \\
\hline \multirow{3}{*}{$\begin{array}{l}\text { Formality } \\
\quad \# 10\end{array}$} & Baseline (10) & - & $1(10 \%)$ & $2(20 \%)$ & $7(70 \%)$ & - \\
\hline & Focal (25) & - & $3(12 \%)$ & $2(8 \%)$ & $20(80 \%)$ & - \\
\hline & $\begin{array}{l}\text { Responses in } \\
\text { Turkish (25) }\end{array}$ & - & $1(4 \%)$ & $9(36 \%)$ & $15(60 \%)$ & - \\
\hline \multirow{4}{*}{$\begin{array}{l}\text { Formality } \\
\quad \# 13\end{array}$} & Baseline (10) & - & $2(20 \%)$ & $3(30 \%)$ & $5(50 \%)$ & - \\
\hline & Focal (25) & - & $6(24 \%)$ & $9(36 \%)$ & $8(32 \%)$ & - \\
\hline & $\begin{array}{l}\text { Responses in } \\
\text { Turkish (25) }\end{array}$ & - & $16(64 \%)$ & $6(24 \%)$ & $3(12 \%)$ & - \\
\hline & & Highly Pol. & Polite & Slightly P. & Less P. & Impolite \\
\hline \multirow{3}{*}{$\begin{array}{l}\text { Politeness } \\
\quad \text { \# } 10\end{array}$} & Baseline (10) & $1(10 \%)$ & $9(90 \%)$ & - & - & - \\
\hline & Focal (25) & $2(8 \%)$ & $23(92 \%)$ & - & - & - \\
\hline & $\begin{array}{l}\text { Responses in } \\
\text { Turkish (25) }\end{array}$ & - & $18(72 \%)$ & $7(28 \%)$ & - & - \\
\hline \multirow{4}{*}{$\begin{array}{l}\text { Politeness } \\
\quad \text { \# } 13\end{array}$} & Baseline (10) & $1(10 \%)$ & $6(60 \%)$ & $2(20 \%)$ & $1(10 \%)$ & - \\
\hline & Focal (25) & - & $15(60 \%)$ & $4(16 \%)$ & $5(20 \%)$ & $1(4 \%)$ \\
\hline & $\begin{array}{l}\text { Responses in } \\
\text { Turkish (25) }\end{array}$ & - & $20(80 \%)$ & $4(16 \%)$ & $1(4 \%)$ & - \\
\hline & & Direct & Conventic & ly Indirect & Noncon & Direct \\
\hline \multirow{3}{*}{$\begin{array}{l}\text { Directn. } \\
\quad \# 10\end{array}$} & Baseline (10) & $7(70 \%)$ & \multicolumn{2}{|c|}{$3(30 \%)$} & \multicolumn{2}{|c|}{-} \\
\hline & Focal (25) & $18(72 \%)$ & \multicolumn{2}{|c|}{$7(28 \%)$} & \multicolumn{2}{|c|}{-} \\
\hline & TR (25) & $19(76 \%)$ & \multicolumn{2}{|c|}{$6(24 \%)$} & \multicolumn{2}{|c|}{-} \\
\hline \multirow{3}{*}{$\begin{array}{l}\text { Directn. } \\
\quad \# 13\end{array}$} & Baseline (10) & $3(30 \%)$ & \multicolumn{2}{|c|}{$7(70 \%)$} & \multicolumn{2}{|c|}{-} \\
\hline & Focal (25) & $13(52 \%)$ & \multicolumn{2}{|c|}{$12(48 \%)$} & \multicolumn{2}{|c|}{-} \\
\hline & TR (25) & $17(68 \%)$ & \multicolumn{2}{|c|}{$8(32 \%)$} & \multicolumn{2}{|c|}{ - } \\
\hline
\end{tabular}

While accepting requests, both participant groups' language was mostly similar in terms of formality, politeness and directness for acceptance speech acts. One noticeable difference points to the focal group's being more formal in their Turkish responses when the superior's request is accepted. 
Table 15. Sample Responses to DCT \#13

\begin{tabular}{ll}
\hline Focal Group & Baseline Group \\
\hline "I'm going to do this quickly." & "Sure, no problem." \\
"Sure, I will bring your car fast." & "Yes, of course." \\
"Your car is on its way to here. & "Sure, I'll be right back." \\
\hline
\end{tabular}

As seen in Table 15, some transferred expressions from their L1, such as "Tabii ki (Of course)" helped focal group establish similarities with the baseline group. However, some other L1-based expressions, especially while talking to someone with higher social status, such as "Hemen getiriyorum" (meaning I'll bring it right away) was not preferred by the native speakers to show acceptance.

\section{Discussion}

\subsection{Understanding Turkish EFL learners' conceptual socialization}

The findings discussed so far indicated that higher level Turkish EFL learners could not produce completely appropriate request and refusal speech acts both in their written and oral productions. Also, the biggest difference between the focal and baseline group occurred at the level of politeness while both groups showed similarity at the level of directness. Based on these results, the present study suggests that Turkish EFL learners' conceptual socialization is influenced by two inter-related processes: classroom instruction and L1 socialization. These two processes will be discussed in this section with evidence from their responses as well as a comparison of their responses with the baseline group's.

First, the baseline group in this study adopted a variety of structures to perform speech acts, while the Turkish EFL learners lacked this pragma-linguistic diversity in their production. One of the common issues observed in the learners' requests was the overuse of 'can' and 'could.' The overuse of 'can' and 'could' provides an advantage for EFL learners to have the same directness level with the native speakers. However, while native speakers mostly preferred to use various forms such as 'Would you mind...?', 'Would it be possible...?', 'Do you think it would be possible....?' in the items which requires being more formal and polite, Turkish learners failed to reach that variety in their requests (see Table 16). This can be related to classroom teaching where 'can' and 'could' for requests are presented first and maybe emphasized more. Also, overemphasis on grammatical forms in English rather than function based teaching in the classrooms might have affected Turkish EFL learners' use of appropriate speech acts in a negative way. Taguchi (2011) asserts that there is "a relationship among the patterns of pragmatic development, types of sociocultural experiences available in the context, and individual differences with the experiences" (p. 624). Turkish learners apparently used what is taught them in the classrooms more as they do not have enough exposure to the language outside the class. When the British Council researched the state of English in Turkish classes in 2015, it revealed that most of the class time is devoted to textbook use without any adaptations. 
Table 16. Sample Responses to DCT \#7

\begin{tabular}{ll}
\hline Focal Group & Baseline Group \\
\hline "Can I leave early today?" & "Would it be possible for me to leave 2 hours earlier \\
"Could I leave early today to go to dentist?" & than usual? I have a dental appointment." \\
"I have an appointment today. Can I leave?" & "Excuse me. I had to schedule a dentist \\
"May I leave 2 hours early?" & appointment this afternoon. Would it be possible for \\
"I need to leave early. Could you give me & me to leave a little early today?" \\
permission?" & "Would I be able to leave early today please. I \\
"I have a terrible toothache. Please give me & really need to get to the dentist." \\
permission. I have to leave early today." &
\end{tabular}

Turkish EFL learners' lack of pragma-linguistic diversity was also evidenced in their use of the verbs 'get, have and take' which can all be translated to Turkish with one word, 'almak.' When the learners uttered 'May I take a napkin?' they were found to be less appropriate linguistically. Similarly, NESs' responses suggested that in requests ' $I$ ' oriented language is more common as in the case of 'Could $I$ have a napkin?.' However, when the learners used expressions like 'Could you give me a napkin?' or 'Could you give me permission?' they were found to be less appropriate.

Second, transferring socio-pragmatic and linguistic features from Turkish to English affected Turkish EFL learners' use of appropriate speech acts negatively. The results show that when the level of formality and politeness is concerned, native speakers used more polite speech acts regardless of whom they were talking to and kept their formality while interacting with inferiors and superiors. However, Turkish EFL learners' level of formality and especially politeness was lower than native speakers in their speech acts. If the students knew the person they were talking to, they used less formal and polite speech acts. It can be because of the sense of solidarity and closeness in Turkish culture that is transferred while communicating in the target language (Zeyrek, 2001). However, when the learners requested something from strangers, they performed similar to NESs by preferring polite requests. This can be because Turkish L1 socialization is similar to English socialization in these contexts. When strangers are concerned, Turkish people get to be more polite.

Overall, Turkish EFL learners' speech act use in Turkish was appropriate, but when they used similar expressions by directly translating the sentences to English, they were found to be less appropriate. For instance, while a request made to a boss in Turkish "Acil bir işim ciktigindan erken cikmama izin verir misiniz?" was found appropriate, its direct translation "I have to leave urgently. Can you give me permission to leave early?" was not found fully appropriate in English. Also, while requesting in Turkish, they did not use 'please' and it was found appropriate by the Turkish raters. Not using 'please' in English, on the other hand, was one of the reasons for low ratings of appropriateness. Therefore, applying the same conventions of L1 socialization in English led learners to use less appropriate expressions (see Table 5 for the other reasons).

Additionally, the use of second-person pronouns in Turkish, sen/siz, similar to tu and vous in French, is enough to make a request polite and formal when necessary (Wierzbicka, 1991). Second person singular (i.e., sen) can be used in informal contexts while the plural one (i.e., siz)can be preferred for formal interactions. As there is only one second person pronoun (you) in English, Turkish EFL learners did not seem to be aware of other ways for making requests in English more polite or formal.

Going back to the raters' comments for their scores, there was no negative comment about EFL learners' use of grammar or vocabulary but it was mostly about the level of politeness in their production due to the inappropriate use of language. Most researchers pointed out that although foreign language learners have the grammatical and lexical knowledge in the target language, they may still fail achieving 
successful communication because of lack of pragmatic competence (e.g., Li, 2015; Ortactepe, 2012; Taguchi, 2012). This is partly because pragmatics requires attending multipart mapping of form, function, meaning, force and context which are intricate, variable non-systematic (Taguchi, 2015). Thus, lack of conceptual socialization in the social environment of the target language leads L2 learners to fail in using appropriate expressions in social interactions (Kecskes \& Papp, 2000). In this respect, Turkish EFL learners' low scoring of appropriateness in the realization of requests and refusals might be because of being unaware of cultural and pragma-linguistic differences in the target language.

\section{Conclusion}

The study aimed to examine Turkish EFL learners' conceptual socialization by analyzing the similarities and differences between native speakers of English and Turkish learners of English in their request, refusal and acceptance speech acts realization in terms of the level of formality, politeness, directness and appropriateness. The findings indicated that Turkish EFL learners could not produce completely appropriate request and refusal speech acts both in their written and oral productions. Also, the learners were found to be less polite and formal than native speakers while using speech acts in most of the contexts in English. This can be mostly because of transfer from L1 socialization to English and lack of pragma-linguistic diversity stemming mostly from the conventions of classroom teaching. In brief, classroom teaching and L1 socialization are two processes that influence EFL learners' conceptual socialization. In addition to these, due to the lack of social context, authentic interaction and engagement in community practice in EFL contexts, the development of conceptual socialization in EFL learners seem to be more challenging and demand external factors or learner investment as mentioned in Ortactepe's (2012) study.

The findings of this study should be treated with caution with regards to basic limitations of it. First, regarding the social situations in DCT, although familiar contexts were aimed to be chosen for the participants, some of the items might have been unavailable to participants in their social lives. For instance, for the item where the participants were asked to refuse to share their notes with their friends (DCT \# 8), a few participants noted in parentheses in the DCT sheet that they would actually share their notes. Similarly, few participants noted that they would not actually borrow money from their schoolmates for DCT \# 4. Therefore, having items that are purely related to participants' social lives could have better reflected what kind of speech acts they would produce in real life contexts. Lastly, this study does not have any data coming from classroom observations; therefore, having studying both classroom instruction and the natural language use of the participants in the classroom atmosphere could have helped the researchers to gain more insights into their speech act realization.

Overall, the findings of the present study point out important pedagogical implications that can inform the future teaching practices, not only in Turkey but also in other EFL contexts. The present study revealed that language learners do not know the appropriate politeness and formality level while using speech acts as they lack conceptual socialization in the target language. However, learning how to carry out social encounters with various people ranging from teachers to friends in different situations is one of the aspects nonnative speakers need to achieve for social competence (Kramsch, 1987). Therefore, more importance should be given in encouraging learners to realize cultural and linguistic differences in speech acts use and help them develop both pragmatic ability and conceptual socialization in the target language. During class hours, instead of focusing on form only, various pragma-linguistic structures used for different social contexts including inferiors and superiors could be presented with the help of instructional technology. For instance, the use of videos or scenes from TV series could help learners raise their awareness about the different structures used in various social contexts (Alver-Yucel, 
2017). Role play activities can also be effective tools to teach speech acts in the classrooms as they can set the social status of the participants and context easily for the learners.

\section{References}

Alver-Yucel, O. (2017). The effects of viewing pre-selected video clips on low level Turkish EFL learners' use of speech acts. (Unpublished master's thesis), Bilkent University, Ankara.

Aliakbari, M., \& Gheitasi, M. (2014). On Iranian EFL learners' pragmatic competence and appropriate use of "request" in English context. Pan-Pacific Association of Applied Linguistics, 18(1), 19-31.

Bardovi-Harlig, K., \& Hartford, B. (1993). Learning the rules of academic talk: A longitudinal study of pragmatic change. Studies in Second Language Acquisition 15, 279-304.

Bikmen, A., \& Marti, L. (2013). A study of complaint speech acts in Turkish learners of English. Egitim ve Bilim (Education and Science), 38(170), 253-265.

Blum-Kulka, S. (1982). Learning to say what you mean in a second language: a study of the speech act performance of Hebrew second language learners. Applied Linguistics, 3(1), 29-59.

Blum-Kulka, S., \& Olshtain, E. (1984). Requests and apologies: A cross-cultural study of speech act realization patterns (CCSARP). Applied Linguistics, 5(3), 196-213. doi: http://dx.doi.org/10.1093/applin/5.3.196.

Cohen, A. D. (1996). Speech acts. In S. L. McKay \& N. H. Hornberger (Eds.), Sociolinguistics and language teaching (pp. 383-420). New York, NY: Cambridge University Press.

Cohen, A. D. (2004). Assessing speech acts in a second language. In D. Boxer \& A. D. Cohen (Eds.), Studying speaking to inform second language learning (pp. 302-327). Clevedon: Multilingual Matters.

Ellis, R. (1992). Learning to communicate in the classroom: A study of two learners' requests. Studies in Second Language Acquisition, 14, 1-23.

Istifci, I. (2009). The use of apologies by EFL learners. English Language Teaching, 2(3), 15-25. http://dx.doi.org/10.5539/elt.v2n3p15.

Kasper, G. (1992). Pragmatic transfer. Second Language Research, 8(3), 203-231.

Kecskes, I. \& Papp, T. (2000). Foreign language and mother tongue. Mahwah, NJ: Lawrence Erlbaum.

Kecskes, I. (2002). Situation-bound utterances in L1 and L2. Berlin; New York: Mouton de Gruyter.

Kecskes, I. (2015). How does pragmatic competence develop in bilinguals? International Journal of Multilingualism, doi: 10.1080/14790718.2015.1071018.

Kilıçkaya, F. (2010). The pragmatic knowledge of Turkish EFL students in using certain request strategies. University of Gaziantep Journal of Social Sciences, 9(1), 185-201.

Lee, C. (2004). Written requests in emails sent by adult Chinese learners of English. Language, Culture, and Curriculum, 17(1), 58-72.

Leung, S. (2001). Language socialization: Themes and advances in research. Working Papers in TESOL \& Applied Linguistics, 1(1), 1-18.

Li, R., Raja Suleiman, R. \& Sazalie, A. (2015). An Investigation into Chinese EFL Learners' Pragmatic Competence. GEMA Online Journal of Language Studies, 15(2), 101-118. 
Lu, D. (2001). Cultural features in speech acts: A Sino-American comparison. Language, Culture and Curriculum, 14(3), 214-23.

Matsumura, S. (2001). Learning the rules for offering advice: A quantitative approach to second language socialization. Language Learning, 51(4), 635-679.

Ming-Fang Lin. (2014). An interlanguage pragmatic study on Chinese EFL learners' refusal: Perception and performance. Journal of Language Teaching \& Research, 5(3), 642-653. doi:10.4304/jltr.5.3.642-653.

Mizıkac1, F. (1991). A sociocultural investigation of speech acts (requests and apologies) in Turkish and English. (Unpublished master's thesis), Bilkent University, Ankara.

Ortactepe, D. (2012). The development of conceptual socialization in international students: A language socialization perspective on conceptual fluency and social identity (advances in pragmatics and discourse analysis). Cambridge: Cambridge Scholars Publishing.

Pinto, D., \& Raschio, R. (2007). A comparative study of requests in heritage speaker Spanish, L1 Spanish, and L1 English. International Journal of Bilingualism, 11(2), 135-155.

Rose, K. (1994). On the validity of the discourse completion task in non-western contexts. Applied Linguistics, 15(1), 1-14.

Schieffelin, B. B., \& Ochs, E. (1986). Language socialization across cultures. New York: Cambridge University Press.

Siebold, K., \& Busch, H. (2015). (No) need for clarity - facework in Spanish and German refusals. Journal of Pragmatics, 75, 53-68. doi:10.1016/j.pragma.2014.10.006.

Taguchi, N. (2015). Instructed pragmatics at a glance: Where instructional studies were, are, and should be going. Language Teaching, 48(1), 1-50. http://dx.doi.org/10.1017/s0261444814000263.

Taguchi, N. (2012). Context, individual differences and pragmatic competence. Bristol: Multilingual Matters.

Taguchi, N. (2011). Pragmatic development as a dynamic, complex process: General patterns and case histories. The Modern Language Journal, 95(4), 605-627.

Wierzbicka, A. (1991). Cross-cultural pragmatics: The semantics of human interaction. Berlin: Mouton de Gruyter.

Willett, J. (1995). Becoming first graders in an L2: An ethnographic study of L2 socialization. TESOL Quarterly, 32, 757-761.

Yule, G. (1996). Pragmatics. Oxford: Oxford University Press.

Zeyrek, D. (2001). Politeness in Turkish and its Linguistic Manifestations. In A. Bayraktaroğlu \& M. Sifianou. Linguistic politeness across boundaries. (pp. 43-73). Amsterdam: J. Benjamins Pub. Co. 


\section{İngilizce'nin yabancı dil olarak kullanıldığı bağlamda kavramsal sosyalleşme: Yabanc1 dil olarak İngilizce öğrenen Türk öğrencilerin rica söz eylemleri kullanımı üzerine bir araştırma}

$\ddot{O} \mathbf{z}$

Kavramsal sosyalleşme, ikinci/yabancı dil öğrenenlerin kavramsal sistemlerini yeni dil ve kültürün işlevsel ihtiyaçlarına uyacak şekilde dönüştürme aşamasında geçirdikleri süreç anlamına gelir (Kecskes, 2002, s. 157). Bu sebeple bu çalışma, yabancı dil olarak İngilizce öğrenen Türk öğrenciler ve ana dili İngilizce olan kişiler arasındaki rica söz eylemi kullanım benzerlik ve farklılıklarını analiz ederek Türk öğrencilerin kavramsal sosyalleşme gelişimini araştırmıştır. Veri, İngilizce öğrenen Türkler (hedef grup) ve ana dili İngilizce olan kişilerden (temel grup) İngilizce ve Türkçe yazılı ve sözlü rica söylem tamamlama aktiviteleri aracilığıyla toplanmıştır. Katılımcıların cevapları resmiyet, kibarlık, doğruluk ve uygunluk seviyeleri açısından bir ölçüt kullanılarak puanlandırılmıştır. Bu çalışmanın bulguları, Türk öğrencilerin ileri seviyede olmalarına rağmen, rica söz eylemlerini ana dili İngilizce olan katılımcılar gibi resmiyet ve kibarlık açısından uygun bir şekilde kullanamadıklarını göstermiştir. Bu bulgular, gerçek dil iletişimin bulunmadığı yabancı dil olarak İngilizce öğrenim bağlamında, öğrencilerin kavramsal sosyalleşme gelişimlerinin sınıf içi ders öğretimi ve Türkçedeki ana dil sosyalleşmelerinden etkilenebildiğini göstermektedir.

Anahtar Kelimeler: Edim bilimsel yeti; kavramsal sosyalleşme; rica söz eylemleri; toplumsal dilbilim; yabancı dil olarak İngilizce

\section{AUTHOR BIODATA}

Merve Şanal is an English instructor teaching at Bilkent University, School of English Language. She graduated from Gazi University, English Language Teaching department in 2010 and received her MA degree at Bilkent University, MA TEFL program in 2016. She completed CELTA and DELTA programs. She is currently working as a Fulbright Foreign Language Teaching Assistant at New York University. Her interests are sociolinguistics and intercultural pragmatics.

Deniz Ortaçtepe is an Assistant Professor in the MA TESOL/TFL program at Middlebury Institute of International Studies at Monterey. Her research interests are second language socialization, intercultural pragmatics, and sociolinguistics. She has published in Language Teaching, Teaching and Teacher Education, Journal of Language Identity and Education, System, and Language and Intercultural Communication. 